How to Cite

Luque, M. P. A., \& Mendoza, M. L. R. (2019). Application of self-assessment and co-evaluation on learning

processes. International Journal of Physics \& Mathematics, 3(1), 1-5. https://doi.org/10.31295/ijpm.v2n1.107

\title{
Application of Self-Assessment and Co-evaluation on Learning Processes
}

\author{
Maria Pamela Almeida Luque \\ Pontifical Catholic University of Ecuador, Manabí Headquarters, Portoviejo, Ecuador \\ Corresponding author email: maria.pa.22@hotmail.com \\ Mariam Liccette Rodriguez Mendoza \\ Pontifical Catholic University of Ecuador, Manabí Headquarters, Portoviejo, Ecuador \\ Email: lisorodriguez@live.com
}

\begin{abstract}
The investigation identified the application of self-assessment and coevaluation in the learning processes in teachers of the School of Basic Education "Nueva Paquisha" of the Nuevo Paquisha community, of the Rocafuerte Canton. The methodology that was used was experimentation, using the survey as an instrument, which allowed us to know that self-evaluation and coevaluation are necessary for students to develop criteria and opinions about their evaluative practices within the classroom. The results obtained improved authentic evaluations in the teaching and learning process, contributing fundamental results to the transformation of information acquired in both the pedagogical day and in daily life, at the same time providing the information that the teacher needs to know to improve and reinforce the knowledge With this practice, the student demonstrates and values the achievements and teachers allow them to confirm the effectiveness of the teaching process.

Keywords---self-assessment, coevaluation, renewed evaluative practice, authentic evaluation.
\end{abstract}

\section{Introduction}

In the self-assessment and co-evaluation, reference is made to any evaluation process whose main purpose is to improve student learning and the teaching-learning processes that take place, as well as integrating students into the evaluation processes (López, 2006; López et al., 2014; López et al., 2013).

The following study is about the scarce explanation of the self-assessment and co-evaluation in the learning processes of the teachers of the School of Basic Education "Nueva Paquisha" of the Nuevo Paquisha community of Canton Rocafuerte determined time of the 2019-2020 school year, we identified the different types of assessments that teachers of this institution provide for the teaching of each of their students, using the different types of tools and activities necessary for the implementation of learning.

The use of self-assessment and coevaluation in the learning process because students acquire new knowledge when designating tasks, are able to reason, reflect, use their creativity for the benefit of their educational purposes and help their peers to reflect, the responsibility they have at the time of their self-correction of the work.

Although some authors report that self-assessment has become a central element of teaching, which aims to study the teaching techniques and methods to be used by each student, showing their level of knowledge, where they are observed the changes to be used to achieve the progress of each one. On the other hand, the co-evaluation allows the student to be guided in the teacher's role, so a change in the role of sharing the function of evaluating, traditionally attributed to the teacher; thus, when instructing the student, the peculiarity of the evaluation process is observed, contributing to the development of learning skills.

The evaluation is a permanent, participatory and reflective process where the difficulties of education are manifested, it guides the search for learning techniques according to the needs of the students because not everyone learns in the same way, so you have to find a way to get them to understand and develop, skills and abilities according to each student to achieve successful learning processes.

ISSN 2632-9417

Received May 05, 2019/Accepted August 30, 2019/Published October 08, 2019 


\section{Materials and Methods}

The research is exploratory, the scientific method and the synthetic analytical were used; For the fieldwork, for the collection of the information, surveys formulated were used to identify the difficulties that exist the self-evaluation and coevaluation applied by the teachers within the classroom in the School of Basic Education "Nueva Paquisha". The surveys were applied to the six teachers of the institution.

\section{Result and Analysis}

\section{Self-evaluation}

It is a process by which a person evaluates himself, where, he identifies and weighs his performance in the fulfillment of a specific task or activity designated (Gisbert, 2002), it is a permanent, participatory and reflective process, which establishes the strengths and weaknesses that are appreciated in learning, so it is a permanent exercise to improve the search for the desired quality, the satisfaction of the community and society in general.

The self-assessment has become a central element of the didactics, whose main objective is to study the teaching techniques and methods to be used by each of the students demonstrating the level of knowledge observed, noting the changes that can be used to achieve the progress of each of them (Pérez, 1997).

The self-assessment allows the teacher to know where their mistakes are, through their students with an easy and participatory exercise such as activities within the classroom.

\section{Self-assessment in the workplace}

It is so common in the environment since most people do not sit down to reflect on what they should improve when performance is evaluated, there are few times that you can analyze where the errors are, that they are commented unconsciously

In this process, he argues (Dove, 1996), that the job skills of positions in general in order to be leaders in their workplace and those around them must face the adversities that arise in any aspect. In this type of evaluation you can mediate in the activities that are most effective and in which you should pay more attention, it helps to correct the habits where they fail before they become a problem, as well as identify if their way of working needs a new approach, being able to investigate other resources to improve.

\section{Coevaluation}

Coevaluation consists in the evaluation of a student's performance through the observation and determinations of their own study partners. Among the advantages that coevaluation can offer, as he proposes (Jiménez, 2006), it allows students to strengthen the control of their own learning, encourages and facilitates their active participation in the learning process; It also states that evaluation enhances cooperation by allowing it to be a shared process, guiding students to make their learning more direct and practical.

In this way, learning is significant where they can participate, correct and learn through their own mistakes; being critical and at the same time they become more analytical, learning to investigate and being demanding (Valero, 2005).

With participation and team cooperation, students become more independent and demonstrate that any work that guides them can face it properly. It can be implemented through group or group evaluations, tasks or assignments are designated for the elaboration of a specific topic, all are evaluated among themselves, making the students participate in all the points and criteria having as results and learning results.

\section{Co-evaluation as an alternative to improve the quality of learning}

Analyzing the results obtained in the investigation of the subject demonstrates that co-evaluation is a reliable and effective instrument to evaluate the quality of learning and contributes to its improvement in the measure that stimulates self-regulation and development of professional skills during the evaluation situation itself. 
This as an alternative, allows to guide the student in the role of the teacher, because a change of role occurs when sharing the function of evaluating, traditionally attributed to the teacher; by instructing the student, in relation to the peculiarities of the evaluation process, he contributes to the development (Widiartini \& Sudirtha, 2019).

\section{Renewed evaluation practices \\ Assessment as teaching of learning}

Teaching has undergone many changes throughout history, evaluation is not going to be its exception, it was previously of letters, over time it is demonstrated that students learn with participation and research demonstrating their knowledge in a normal school day. It has been shown that students have become analytical, participatory and evaluative, thanks to the teaching and learning that was renewed through professional skills during the evaluation (Frola, 2008).

Types of evaluation practices

Investigating the types of evaluation that exist, we can observe that they are: summative evaluation and formative evaluation; The summative evaluation is divided into two: Total summative evolution and partial summative evaluation, as shown in Figure 1.

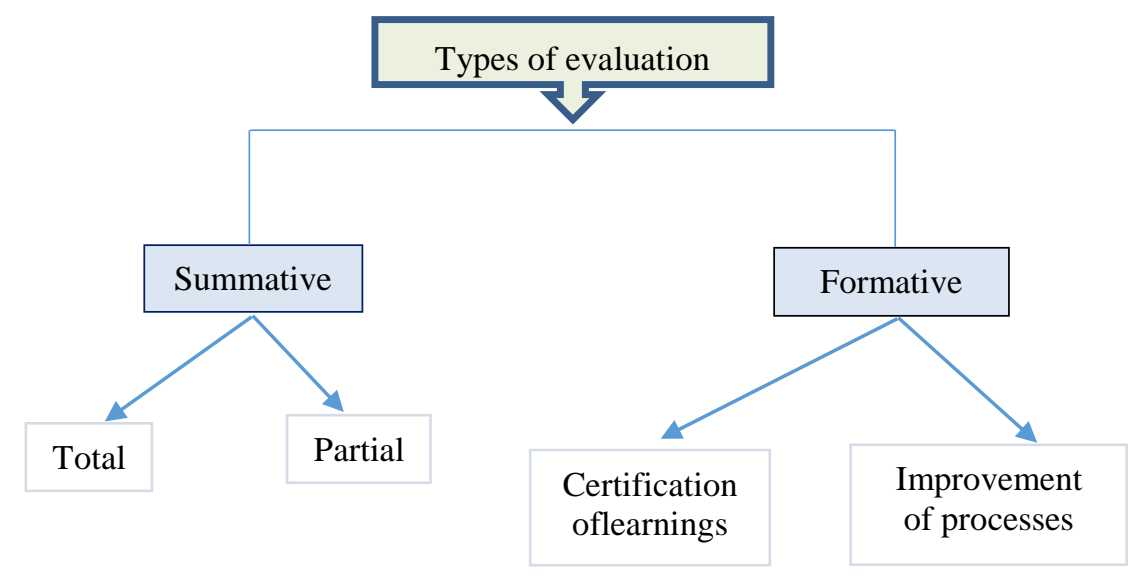

Figure 1. Types of evaluation

The total summative, characterized by the certification of the learning achieved by the students and origin of their promotion At the level, centered on the final product or terminal evaluation, there is the use of instruments of maximum objectivity.

Partial summative evaluation is the final educational achievement as the integration of partial achievements and the origin of their level promotion.

There is also the evaluation in established and terminal periods here they are used as objective instruments, written and oral exams, for the final test, the partial tests, and product analysis.

Formative Evaluation, characterized by certification of learning and improvement of processes, the continuous evaluation with the use of diverse instruments such as direct observation, product analysis, rubrics, scales, checklists, evaluation guidelines, and oral questions, portfolios (Seralurin \& Ermawati, 2019).

The evaluation for learning, characterized by the integration of teaching, with the evaluation where students are involved in their own progress, immediate and permanent feedback, relying on the students' responses, this is continuously adjusted with instruction and involves students in the self-evaluation and coevaluation, maintaining constant standard.

Authentic evaluation. This evaluation assesses learning rhythms.

No todos los estudiantes tienen un mismo ritmo de aprendizaje, por lo que se debe realizar diferentes pruebas para saber el nivel de conocimiento en que se presenta o alguna discapacidad que no se ha podido notar hasta el presente (Ángel, 1998), la mayoría de los estudiantes necesitan una explicación clara para entender lo expuesto en una hora normalbde clase, un pequeño grupo de estudiantes necesitan explicaciones amenas y explicitas para que entienda de que tema realmente se habla y que estos puedan participar en el grupo. 


\section{Motivación incluida}

Not all students have the same learning pace, so different tests must be carried out to determine the level of knowledge in which it is presented or a disability that has not been noticed until The present (Ángel, 1998), the majority of students need a clear explanation to understand what is stated in a normal class time, a small group of students needs pleasant and explicit explanations so that they understand what topic is really talked about and that they can participate in the group.

Prior knowledge

It is important that the teacher knows how to handle the topic to be treated with extensive knowledge of the subject, students apart from enriching this knowledge, are analytical and investigative and above all become the main critics when evaluating them. Through the advances in technology, students and teachers use these means to investigate and know what else these issues tell us using the different techniques that technology education offers us.

Education has made great progress thanks to the Techniques of Informatics and Communications (ICTs), with it it has been possible to cover with necessary information enriches the knowledge for the evaluation of students and teachers according to the mediated educational standards (Molina, 2014). According to the methodology applied, as a result, that evaluations are necessary for students and teachers, helping students to be critical and responsible for their actions related to the lessons learned during their life in the institution, family and professional environment.

The data obtained during the investigation allowed to know the difficulties that are present within the educational system of the school, with these results you can optimize the method of practical teaching of each of the areas in which you need to reinforce and improve in the field educational; Self-evaluation and Co-evaluation are considered as the transformation of educational practice, oriented to the regulation of learning, providing relevant information on how students are learning and what are the greatest difficulties, both individually and in groups, in this way it will be known the shortcomings that need to be reinforced during learning (Mahayukti et al., 2017).

The techniques used by teachers are necessary, are minutes to apply all kinds of assessments to assess the criteria and responsibilities of each student. In surveys conducted, $90 \%$ of teachers apply assessment techniques to students for self-realization as a person. Students must be involved in their school activities, express their criteria spontaneously, be self-critical to achieve their proposed goals and teacher participation is to let them be responsible for academic acts.

According to data collected $50 \%$ of teachers apply self-assessment to students through previous experiences, questions to perform their criteria analysis. The students indirectly carry out various kinds of assessments, they are participating in the development of the development processes, and they show interest in learning through their healthy comments towards their peers and teachers.

Another of the results obtained in the investigations is related to the fact that $94 \%$ of the students are attracted to the different evaluation techniques, they discover their skills to experiment, and they are able to identify the mistakes of their classmates with responsibility. The evaluation models are techniques to verify the range of academic benefits of the students, this medium helps the teaching-learning processes.

\section{Conclusion}

Self-assessment and co-evaluation are necessary to strengthen the skills of their students during this learning process, this will facilitate their pedagogical work and enrich the educational environment. Applying these assessments will help students to perform both in their classroom and in the environment where they live. In this research, according to the teachers, the criteria of the students are important because they have to express themselves and give opinions about what they think, and thus develop their philosophy.

\section{Acknowledgments}

Expression of gratitude to God for allowing us to be here to our families for unconditionally supporting us to get ahead, to our teacher Dr. María Rodríguez for sharing her knowledge being a great teacher who gave us her unconditional help in the preparation of this article, to this prestigious Pontifical University Catholic University of Ecuador with Manabí headquarters, for opening its doors to conduct our fourth level studies.

Absolute gratitude to our educational institutions for giving us the support we need to continue with our studies, preparing academically to share our knowledge with our fellow teachers and students. 


\section{References}

Ángel I. (1998). La cultura escolar en la sociedad neoliberal, Madrid: Morata. 3era edcón. ISBN:84-7112-43-9. edu.jalisco.gob.mx/ciie/sites/edu.jalisco.../la\%20cultura\%20escolar_0.pdf

Dove, M. (1996), Autoevaluación. https://tminfoedithconhdos.wordpress.com/2018/09/13/actividad-de-evaluacion$1-2 /$

Frola, P. (2008). Competencias Docentes para la Evaluación. México: Editorial Trillas.

Gisbert, M. (2002). La evaluación, Materiales formativos multimedia en la red. Guía práctica para su diseño. Sevilla: SAV.

Jiménez, J. (2006). Innovación, aprendizaje organizativo y resultados empresariales.

López et al., 2014;

López, 2006;

López-Pastor, V. M. (2013). Nuevas perspectivas sobre Evaluación en Educación Física. Revista de Educación Física, 29 (3), 4-13.

Mahayukti, G. A., Gita, I. N., Suarsana, I. M., \& Hartawan, I. G. N. Y. (2017). The effectiveness of self-assessment toward understanding the mathematics concept of junior school students. International Research Journal of Engineering, IT \& Scientific Research, 3(6), 116-124.

Molina, (2014). La evaluación auténtica de los procesos educativos. Revista Iberoamericana de Educación, (64), 11 25.

Pérez, L. (1997). La evaluación dentro del proceso enseñanza- aprendizaje. Recuperado de http:// www.hemerodigital.unam.mx/ ANUIES/ipn/academia/11/sec_4.htm

Seralurin, Y. C., \& Ermawati, Y. (2019). Influence of self-assessment system, taxation understanding, and discrimination toward ethics of tax evasion. International Research Journal of Management, IT and Social Sciences, 6(5), 267-278. https://doi.org/10.21744/irjmis.v6n5.745

Valero, M. (2005). Autoevaluación y co-evaluación: estrategias para facilitar la evaluación continuada. Actas del I Congreso Español de Informática.

Widiartini, N. K., \& Sudirtha, I. G. (2019). Effect of KWL learning method (know-want-learn) and self-assessment on student learning independence vocational high school. International Journal of Social Sciences and Humanities, 3(2), 277-284. https://doi.org/10.29332/ijssh.v3n2.331

\section{Biography of Authors}

\begin{tabular}{|l|l||}
\hline \hline & $\begin{array}{l}\text { María Pamela, } \\
\text { Study at the Eloy Alfaro Lay University, Bachelor of Science in Education, Master of } \\
\text { Innovation student at the Pontifical University of the Catholic University of Ecuador, } \\
\text { Manabí headquarters. } \\
\text { Email: maria.pa.22@ @otmail.com } \\
\text { malmeida4350@pucem.edu.ec }\end{array}$ \\
\hline \hline
\end{tabular}

